\title{
Discussion on Financial Talent Cultivation in the Context of Big Data*
}

\author{
Xiaoyu Liu \\ Harbin Finance University \\ Harbin, China
}

\begin{abstract}
This paper proposes the approaches to the cultivation of financial talents in the era of big data, which is conducive to providing applied inter-disciplinary financial talents to the society and providing strong support for China's economic and financial development.
\end{abstract}

Keywords—big data; financial talents; experimental teaching

\section{INTRODUCTION}

Big data era, the informationization of financial development on the current and future financial practitioners put forward higher request information financial as gathered financial business emerging information technology in the integration of new forms of operation in the financial industry, is a large number of high-end talents gathered at the university of technology intensive industry at present domestic financial education level and modern information technology and financial markets compared to endless innovation, there are obvious gap. In 2015, China's interest rate liberalization reform was completed, banking competition intensified, and the market-based pricing system for financial products and services was fully established. Financial institutions should not only reflect the principle of customer's comprehensive contribution and risk compensation in product pricing, but also fully consider factors such as industry competition and customer sensitivity, and finally achieve a balance between costs and benefits, prices and market share.

Especially the large financial institutions as a market leader, pricing power not only determines the agency's profits and also an important impact on the financial order, so the future demand for financial products pricing talent very urgently the booming of Internet finance, integration is a trend of online Visible, financial industry era of change and challenge, colleges and universities financial talents also faces new challenges and problems to be solved in university personnel training system is according to the requirements of talents training target and specification will be structured

*Fund: Higher education teaching reform research project :Research on the hyper-network model of financial talent cultivation in the context of big data (SJGY20180191); The research project of the basic scientific research project of the province of Harbin Finance University, which is based on the financial ethics perspective, the research stage of the financial development evaluation of the county area (2017-KYYWF-0088); Heilongjiang youth innovation talent training program project: Research on risk contagion and prevention and control strategy in financial network based on SIR and SIS combined model (UNPYSCT-2018051) design, teaching content mainly involves two aspects of curriculum system and teaching content The talent cultivation system is not only the concentrated reflection of the idea of talent cultivation, but also the concrete embodiment and realization carrier of the goal and specification of talent cultivation.

\section{The Problems FACED BY FinANCIAL PERSONNEL TRAINING IN THE CONTEXT OF BIG DATA}

\section{A. The Courses of Finance Are Very Complicated}

Finance professional course is more, all kinds of teaching contents has both a macroscopic, comprehensive and individual WeiGuanXing motion rule of financial economy itself is the feature of the management methods of generalization and sublimation but its complicated contents, basic concept and basic theory in the majority in the actual teaching process, as a result of the limitation of teaching time, selection of appropriate knowledge point, so how to in limited time selection of appropriate knowledge point is the challenge for the teacher, the teacher must keep up with the development of finance, accurately grasp the difficult point, choose the content of the course and re-engineering However, some students feel that they need to remember too many nouns and terms in the course of learning. They have many knowledge points and are abstract and difficult to understand, so they have a sense of fear for this course.

In addition, the traditional teaching mode is used to the heavy theory, light practice, for example in the teaching of the operation mechanism of financial markets and financial

instruments operating principle of the practical content, teacher single explanation way is very difficult to make students truly master the knowledge As a teacher should be appropriate to adjust the content, the different specialized student knowledge of money and banking needs exist similarities and differences, not to all classes professional explanation of exactly the same content But in the actual classroom teaching, the teacher often ignored in the process of teaching should be to distinguish the different teaching object, often adopts the unified teaching plan in turn teach the same level different specialized student this approach ignores the professional students of different levels on the differences of knowledge structure of teachers in teaching content arrangement optional the gender is big, do not do the students need most knowledge to them, and often leads to the 
same education background of different professional course knowledge point the extent of difference is bigger, it will affect the level of teaching and practical teaching effect.

\section{B. The Classroom Teaching Method Is Monotonous}

Along with the rapid development of economic and financial situation both at home and abroad and the further research of the teaching reform of colleges and universities, the monetary banking problems existing in the course teaching gradually increase the teaching mode of most universities and colleges of undergraduate course boring, for example, single teaching method, students' enthusiasm to take the initiative to acquire knowledge is poor due to the finance curriculum theory knowledge, for the traditional teaching methods focus on courses, students often reflect content boring, often leads to at the beginning of the lecture, there is no stimulate students' interest in learning, making students lose confidence The single way of teaching while give full play to teachers' leading role, but because the students lack of financial knowledge background, single teaching theory cannot directly into the rational knowledge of students If teachers according to the traditional teaching method of interpretation of the boring theory knowledge, adopt the method of cramming education must make students difficult to understand and master the content of the course, causes the student to have the negative emotions to the course, students' learning initiative and enthusiasm Therefore, in terms of teaching methods, teachers must strengthen students' perceptual knowledge and take students as the leading role. On this basis, students complete the leap from perceptual to rational through self-learning.

\section{Single Way of Teaching Evaluation}

Teaching evaluation is based on the cognitive behavior constraints and incentives to ensure the smooth realization of the goal of learning, it is a test of the student learning conditions stipulated in the traditional form of teaching appraisal is the teaching system of attendance and the quantitative indexes such as the final test at ordinary times, this means in the final exam as the only criterion and assessment method, the teacher test to the students draw the examination scope. Even some teachers do not pay attention to the state of involvement in the learning process of students. Therefore, it is difficult to objectively, comprehensively and impartially reflect students' learning situation in the test results. On the other hand, it is difficult to enhance students' learning interest in a short period of time.

\section{The PRoblems Faced B y FinANCIAL PERSONNEL TRAINING IN THE CONTEXT OF BIG DATA}

\section{A. Improving the Classroom Teaching Quality}

Classroom teaching is the students to obtain professional knowledge and the basic way to improve the cognitive ability, to attach importance to education, teaching reform to cultivate conforms to the current economic development needs of financial talent First of all, to conduct market research To probe into the different areas of research and visit, learn applied financial talented person's demand of each region, perfecting financial talent training Second, increase employment tracking. Employment staff to effectively increase employment tracking investigation and research, timely feedback of satisfaction and the talent cultivation of unit of choose and employ persons, understand the idea of graduates and the suggestion, provide the basis for the education teaching reform again, setting up reasonable curriculum system adheres to the standard of students, adjust the curriculum system setting, make the teaching content in accordance with the rapid development of financial industry and practical need in national regions, to improve students' employment adaptability. Curriculum should strengthen the multi-disciplinary comprehensive, already let the students master the basic knowledge of economic management accounting and other kinds of professional, also let the students learn about social and moral accomplishment, in addition to expand students knowledge of natural science knowledge Encourage teachers comprehensive innovative experiment courses and research programmes, encourage undergraduate students to participate in scientific research activities.

\section{B. Strengthening the Teachers Troops Construction}

In the era of big data, university teachers have the basic of digital teaching ability is not enough teachers should take the initiative to adapt to the digital development of higher education, understand the data to support decision-making of teaching culture, improve data analysis ability, and a clear understanding to the era of big data university curriculum change on their professional development put forward severe challenges, to realize the significance of adapt to the era of big data requirements. In the aspect of teaching staff construction to the introduction of high-level professionals, has introduced main of associate professor above title teacher, Dr Hiring finance as far as possible at the same time to strengthen the training of the existing teachers, training of financial software operating practice course database technology and application of network technology and application of online instructional design skills data analysis technology and study analysis, etc.

\section{Attention to the Social Practice}

Using big data technology to explore and develop international practice teaching, set up to adapt to the era of big data financial talent practice ability system of the development of the school as an education base but also need to emphasis on the importance of practice, the finance should be established stock exchange simulation experiment courses in financial markets, lets the student in the campus can experience and learn practical knowledge in financial markets, Schools should also strengthen cooperation with enterprises to provide practice places for students, invite enterprise professionals to lecture on campus, and jointly study financial topics with students in school. The school sends students to financial enterprises for school-enterprise cooperation, and organizes the school teachers to the enterprise unit training, which can better teach students practical knowledge. Enterprises should also bear the corresponding social responsibility to accept campus internship students and provide them with practical training. 
Innovation and practice are combined together. Without practice, innovation cannot be achieved. Only by combining theoretical knowledge with practice can innovation be made and new things needed by society can be explored.

\section{Intensive Experimental Teaching}

Experimental teaching is the core content of practice teaching in colleges and universities, it is to learn professional knowledge and skills in the classroom books and apply it in practice, and in the process of applying to further expand and deepen professional knowledge, achieve the goal of skilled, professional skill With the increase of the proportion of the experimental teaching in higher education, financial discipline in the groping how to more effectively will experiment into subject The financial opening experiment, with the aid of computer platforms and various application software, computer simulation experiment on the operation, emphasizes the student's own brain, lets the student with financial knowledge, on the platform attempts to establish a reasonable financial quantitative model to describe the actual problem, with the aid of computer software, econometric methods, reasoning calculated so as to solve the actual problem, to cultivate students' innovation ability of scientific computing. With platform for financial and supply chain financial model of big data for the financial times, for financial talents must have real-time analysis data such as data mining, data computing capability with the progress of science and technology, division of labor is more and more refined, the level of social and economic increase steadily, and the financial talents with innovative consciousness and ability is essential for economic and social, but also the main force of financial competition.

At present, the main trends of development of financial analysis in the financial market is a quantitative analysis for a particular object, establish proper mathematical model, by setting up financial LABS, financial modeling and programming elective courses, such as learning SAS software Matlab software C language, etc., can develop the students' ability of programming calculation ability of data mining and analysis ability, and through the abstract problems Hypothesized model building, the method analysis of hypothesis test, with the aid of computer software, solve and verify the financial related issues, is a good way to exercise the students' ability of financial modeling, to adapt to the demand for the development of the financial analysis.

\section{CONCLUSION}

Above all, a reasonable teaching mode requires teachers to constantly sum up experience, maintain a high level of enthusiasm, and the unremitting pursue advocated abandoning the traditional teaching mode teachers guide students in teachers imparting theoretical knowledge in the process of money and banking, experience the financial activities of practice, through the construction of cooperation and exchange of creative cognitive thinking, which makes students master the disciplines of theoretical knowledge As a teacher, we should keep learning and improve our professional level. A reasonable teaching mode is the basis to guarantee the teaching quality and one of the important links to improve the teaching effect.

\section{REFERENCES}

[1] Zhu Jianping. The impact of big data on college teaching, China University Teaching, 09, 2014. pp.41-44.

[2] Ren Jiangsong. Regional orientation and countermeasures of financial talents training in local universities, chinese higher education, 09, 2012. pp.56-60.

[3] $\mathrm{Hu}$ Shihua. A probe into the practical teaching of finance undergraduate major in colleges and universities, journal of southwest china normal university, 01, pp.56-60. 